(C) 2018 by the Arizona Board of Regents on behalf of the University of Arizona. This is an Open Access article, distributed under the terms of the Creative Commons Attribution-NonCommercial-ShareAlike licence (http://creativecommons.org/licenses/by-ncsa/4.0/), which permits non-commercial re-use, distribution, and reproduction in any medium, provided the same Creative Commons licence is included and the original work is properly cited. The written permission of Cambridge University Press must be obtained for commercial re-use.

\title{
PROJECTIONS FOR FUTURE RADIOCARBON CONTENT IN DISSOLVED INORGANIC CARBON IN HARDWATER LAKES: A RETROSPECTIVE APPROACH
}

\author{
Thomas M Blattmann ${ }^{1 *} \cdot$ Martin Wessels $^{2} \cdot$ Cameron P McIntyre $^{1,3} \cdot$ Timothy I Eglinton $^{1}$ \\ ${ }^{1}$ Geological Institute, ETH Zürich, Sonneggstrasse 5, 8092 Zurich, Switzerland. \\ ${ }^{2}$ ISF Langenargen, Germany. \\ ${ }^{3}$ Laboratory of Ion Beam Physics, ETH Zürich, Switzerland; current address: SUERC Glasgow, United Kingdom.
}

\begin{abstract}
Inland water bodies contain significant amounts of carbon in the form of dissolved inorganic carbon (DIC) derived from a mixture of modern atmospheric and pre-aged sources, which needs to be considered in radiocarbon-based dating and natural isotope tracer studies. While reservoir effects in hardwater lakes are generally considered to be constant through time, a comparison of recent and historical $\mathrm{DI}^{14} \mathrm{C}$ data from 2013 and 1969 for Lake Constance reveals that this is not a valid assumption. We hypothesize that changes in atmospheric carbon contributions to lake water DIC have taken place due to anthropogenically forced eutrophication in the 20th century. A return to more oligotrophic conditions in the lake led to reoxygenation and enhanced terrigenous organic matter remineralization, contributing to lake water DIC. Such comparisons using $\mathrm{DI}^{14} \mathrm{C}$ measurements from different points in time enable nonlinear changes in lake water DIC source and signature to be disentangled from concurrent anthropogenically induced changes in atmospheric ${ }^{14} \mathrm{C}$. In the future, coeval changes in lake dynamics due to climate change are expected to further perturb these balances. Depending on the scenario, Lake Constance $\mathrm{DI}^{14} \mathrm{C}$ is projected to decrease from the 2013 measured value of $0.856 \mathrm{Fm}$ to $0.54-0.62 \mathrm{Fm}$ by the end of the century.
\end{abstract}

KEYWORDS: carbon cycle, DIC, Lake Constance, reservoir effect, Suess Effect.

\section{INTRODUCTION}

By the end of this century, the radiocarbon $\left({ }^{14} \mathrm{C}\right)$ content of $\mathrm{CO}_{2}$ in the atmosphere is projected to decline and reach a ${ }^{14} \mathrm{C}$ age equivalent of 2000 years before present following businessas-usual emissions of fossil fuels (Graven 2015). This marked decline will be followed by reductions in ${ }^{14} \mathrm{C}$ content of carbon reservoirs exchanging with the atmosphere, including biospheric, lacustrine, and oceanic pools. This decline in ${ }^{14} \mathrm{C}$ isotopic composition is known as the Suess Effect after Hans Suess, who became the first to observe this effect in 1955 (Suess 1955). Beginning in the 1950 s, nuclear weapons testing introduced bomb-derived ${ }^{14} \mathrm{C}$ into the atmosphere nearly doubling its content within the course of a decade (Broecker and Walton 1959a; Levin and Kromer 2004). This perturbation in atmospheric ${ }^{14} \mathrm{C}$ has propagated through Earth surface reservoirs in communication with the atmosphere at varying rates (Graven 2015).

In addition to carbon sourced from the atmosphere, water bodies located in areas of limestone and karst receive carbonate ions sourced from the chemical weathering of calcareous bedrock in the catchment:

$$
\begin{gathered}
\mathrm{CaCO}_{3}+\mathrm{CO}_{2}+\mathrm{H}_{2} \mathrm{O}=\mathrm{Ca}^{2+}+2 \mathrm{HCO}_{3}^{-} \\
2 \mathrm{CaCO}_{3}+\mathrm{H}_{2} \mathrm{SO}_{4}=2 \mathrm{Ca}^{2+}+\mathrm{SO}_{4}^{2-}+2 \mathrm{HCO}_{3}^{-}
\end{gathered}
$$

Carbonate rocks are typically of ancient geological origin, giving rise to contributions of ${ }^{14}$ C-dead carbon to dissolved inorganic carbon (DIC) pools (e.g., Z. Liu et al. 2017; Ishikawa et al. 2015). DI ${ }^{14} \mathrm{C}$ stemming from limestone weathering depends on the reaction stoichiometry with carbonic (reaction 1) and sulfuric acid (reaction 2) giving rise to half modern and

\footnotetext{
*Corresponding author. Email: thomas.blattmann@erdw.ethz.ch.
} 


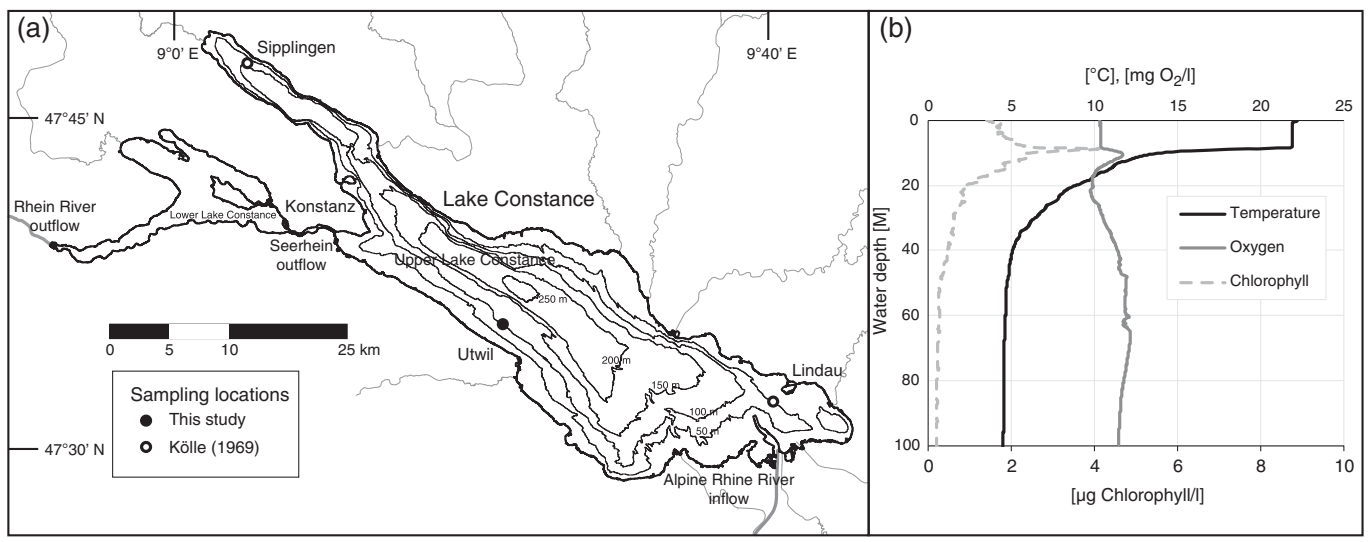

Figure 1 (a) Map of Lake Constance (IGKB 2016) showing sampling locations for this study near the township of Utwil (filled circle) and adjacent to the townships of Sipplingen and Lindau (open circles) from Kölle (1969). Part (b) shows water column parameters recorded during sample collection on August 14, 2013. The upper $20 \mathrm{~m}$ of the water column are characterized by primary productivity with a peak in chlorophyll and oxygen concentrations between 8 and $12 \mathrm{~m}$. Water temperature decreases steadily with depth until $40 \mathrm{~m}$, below which it remains relatively constant.

completely dead signatures, respectively. In contrast, silicate weathering delivers DIC sourced exclusively from atmospheric or soil pools, which are a source of modern carbon:

$$
2 \mathrm{KAlSi}_{3} \mathrm{O}_{8}+2 \mathrm{CO}_{2}+3 \mathrm{H}_{2} \mathrm{O}=\mathrm{Al}_{2} \mathrm{Si}_{2} \mathrm{O}_{5}(\mathrm{OH})_{4}+4 \mathrm{SiO}_{2}+2 \mathrm{~K}^{+}+2 \mathrm{HCO}_{3}^{-}
$$

Hardwater lakes are most affected by the effect of ${ }^{14} \mathrm{C}$-depleted DIC stemming from limestone weathering (Keaveney and Reimer 2012) with the consequence of aquatic organisms assuming the $\mathrm{DI}^{14} \mathrm{C}$ isotopic composition of the water body from which the carbon is sourced (Broecker and Walton 1959b). In total, the ${ }^{14} \mathrm{C}$ content of lake water DIC depends on the DIC inputs (river runoff, groundwater discharge, atmospheric input) and outputs (river outflow, groundwater leakage, degassing to the atmosphere, fixation by photosynthesis and calcification, and radioactive decay) (Yu et al. 2007). The resulting reservoir effect needs to be taken into account for assessing the age of aquatic materials (e.g. shells, organic matter) and for tracing pathways of carbon in food webs and in the environment (Guillemette et al. 2017).

In the post-industrial era, hardwater lakes will be impacted by the residual bomb-spike, as well as contributions from anthropogenic emissions of ${ }^{14} \mathrm{C}$-depleted $\mathrm{CO}_{2}$ that are superimposed on an already ${ }^{14} \mathrm{C}$-depleted reservoir due to limestone weathering. Here we present a case study from Lake Constance (Figure 1) examining changes in ${ }^{14} \mathrm{C}$ isotopic composition of lake water DIC over time. We present results from samples collected in 2013 and combine these with historical data from 1969 and discuss how changes in atmospheric carbon contributions to DIC are modulated over time. A prediction for $\mathrm{DI}^{14} \mathrm{C}$ content is made for Lake Constance in the year 2100 , which may apply similarly to other hardwater lakes and rivers.

\section{STUDY SITE AND METHODS}

Lake Constance, the second-largest perialpine lake in central Europe, formed after the Last Glacial Maximum in the wake of retreating glaciers (Wessels 1998). Lake Constance is composed of two basins - the Upper Lake Constance and Lower Lake Constance basins. Upper Lake Constance, the subject of this investigation, covers an area of $472 \mathrm{~km}^{2}$, holds $47.6 \mathrm{~km}^{3}$ of water with a maximum depth of $251 \mathrm{~m}$ as documented by the Internationale Gewässerschutzkommission für den Bodensee (IGKB 2009, 2016). The watershed encompasses 
an area of $11,438 \mathrm{~km}^{2}$, of which $6119 \mathrm{~km}^{2}$ is drained by the Alpine Rhine (IGKB 2009), which delivers $62 \%$ of the water flux (Gilfedder et al. 2010). Total annual water influx is $12.02 \mathrm{~km}^{3}$, giving water a theoretical residence time of $4-5$ years in the lake (Gilfedder et al. 2010). Lake Constance is subject to annual cycles of water column stratification and mixing, which are driven by changes in temperature, leading to episodes of bottom water oxygen replenishment (Bäuerle et al. 1998). Thermal destratification does not proceed to completion every year and is increasingly affected by rising lake temperatures (Bäuerle et al. 1998; IGKB 2015). The widespread occurrence of limestone in the catchment makes Lake Constance a typical hardwater lake with calcite precipitation tied to seasonal primary productivity (Wessels 1998).

The sampling location FG $\left(47^{\circ} 35^{\prime} 59^{\prime \prime} \mathrm{N}, 9^{\circ} 21^{\prime} 29^{\prime \prime} \mathrm{E}\right)$ located offshore of the township of Utwil is described in IGKB (2009). In brief, location FG is characterized by sediment supply predominantly of autochthonous origin and is a reference location for lake primary productivity (Fuentes et al. 2013a). A depth profile of water samples was collected on 14.08.2013 from location FG using a Hydro-Bios (Kiel, Germany) Niskin rosette sampler. Additionally, a CTD probe (conductivity, temperature, and depth) equipped with sensors for turbidity, oxygen, and chlorophyll (Sea \& Sun Technologies) was used for the characterization of the water column. Data were collected at $2 \mathrm{~Hz}$ and was continuously lowered at about $0.5 \mathrm{~m} / \mathrm{s}$, collecting about 400 values for the $100 \mathrm{~m}$ profile collected at location FG. Water samples were collected in 1-L glass bottles, poisoned with $100 \mu \mathrm{L}$ saturated $\mathrm{HgCl}_{2}$ solution, and sealed with Apiezon $\mathrm{N}$-greased ground joint glass stoppers (Blattmann et al. 2013). Water samples were stored at room temperature in the dark until ${ }^{14} \mathrm{C}$ analysis of dissolved inorganic carbon $\left(\mathrm{DI}^{14} \mathrm{C}\right) .40 \mathrm{~mL}$ of each water sample was transferred to a $60 \mathrm{~mL}$ glass vial sealed by Teflon-coated silicon septum cap. The headspace was purged with helium for $2-4 \mathrm{~min}$ at $100 \mathrm{~mL} / \mathrm{min}$. Samples were acidified with orthophosphoric acid and purged for $8 \mathrm{~min}$ (assessed as optimal for maximizing $\mathrm{CO}_{2}$ yields; Blattmann et al. 2013). Purged $\mathrm{CO}_{2}$ was captured, quantified, and graphitized using an AGE 3 system (Wacker et al. 2010), and then analyzed using a MICADAS accelerator mass spectrometry (AMS) system (Synal et al. 2007) at the Laboratory of Ion Beam Physics at ETH Zurich. A duplicate of one water sample reproduced ${ }^{14} \mathrm{C}$ content within instrumental error (i.e., $\pm 0.002 \mathrm{Fm})$

Kölle (1969) reports Lake Constance DI ${ }^{14} \mathrm{C}$ adjacent to the towns Sipplingen $\left(47^{\circ} 47^{\prime} 52^{\prime \prime} \mathrm{N}, 9^{\circ} 5^{\prime}\right.$ $\left.44^{\prime \prime} \mathrm{E}\right)$ and Lindau $\left(47^{\circ} 32^{\prime} 46^{\prime \prime} \mathrm{N}, 9^{\circ} 40^{\prime} 53^{\prime \prime} \mathrm{E}\right)$. These $\mathrm{DI}^{14} \mathrm{C}$ data were converted from their reported $\mathrm{Bq} / \mathrm{kgC}$ units to fraction modern (Fm) units following Stenström et al. (2011; equation 42). For surface and deep waters, $-8 \%$ for $\delta^{13} \mathrm{C}_{\text {DIC }}$ is adopted for fractionation correcting the ${ }^{14} \mathrm{C}$ concentration data reported by Kölle (1969). Lake Constance waters below the photic zone (i.e. greater than $20 \mathrm{~m}$ of water depth) display steady $\delta^{13} \mathrm{C}_{\text {DIC }}$ values centered around $-8 \%$, irrespective of season (Hirschfeld 2003). Surface water $\delta^{13} C_{\text {DIC }}$ is variable depending on the season, however given that samples were collected on April 17, 1969, we assume that the spring primary productivity bloom, which leads to an increase in surface water $\delta^{13} \mathrm{C}_{\text {DIC }}$ (Hollander and McKenzie 1991; Hirschfeld 2003), had not yet initiated. This assumption is supported by monthly timeseries records from Lake Constance that show that by April 15, 1969, (1) temperatures of surface waters had not warmed above their winter values of $5^{\circ} \mathrm{C}$ and (2) surface water phosphate concentrations remained steady, indicating low algal growth. Given these historical constraints, some uncertainty remains in fractionation correction of data reported by Kölle (1969) and so the results encompass the spread from a sensitivity analysis allowing $\delta^{13} \mathrm{C}_{\text {DIC }}$ values to vary in the range $-8 \pm 3 \%$. The $\pm 3 \%$ amplitude covers seasonality-induced changes in $\delta^{13} \mathrm{C}_{\text {DIC }}$ observed in Lake Constance (Hirschfeld 2003). 


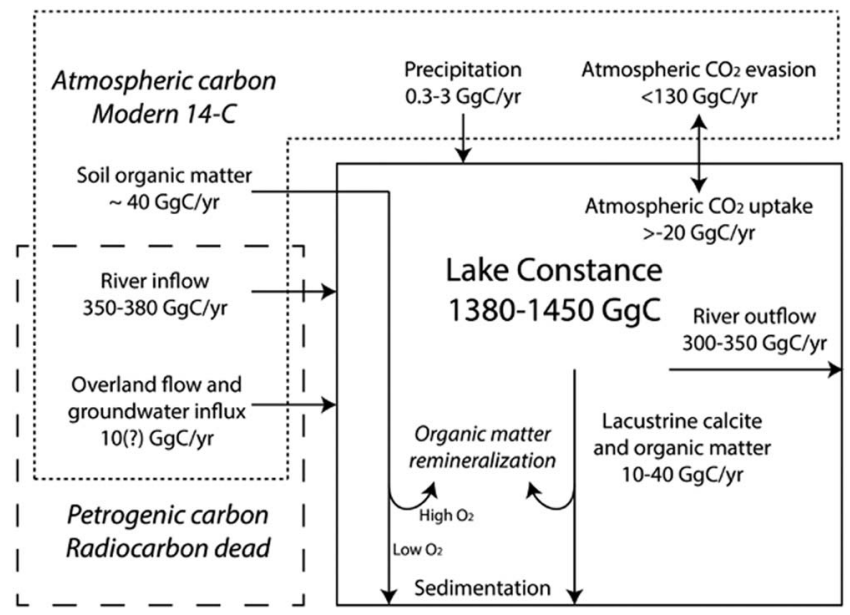

Figure 2 Model overview of DIC sources and fluxes in the Lake Constance system. The size of the DIC pool in Lake Constance varies within 1380-1450 GgC. River inflow and outflow constitute the largest DIC source and sink respectively. Further DIC inputs include overland and groundwater contributions and direct contributions from rainwater into the lake. Additional sinks of DIC include the sedimentation of calcite and organic matter formed in the lake. Furthermore, carbon dioxide evades from lake water into the atmosphere and may either be positive (net $\mathrm{CO}_{2}$ flux from the water to the atmosphere) or negative, ranging from a total net flux of -20 to $+130 \mathrm{GgClyr}$. Terrestrial organic matter is subject to partial remineralization within the lake, with organic matter remineralization efficiency depending on water column oxygen content. The different DIC sources are characterized by varying proportions of atmospheric and petrogenic carbon.

\section{RESULTS AND DISCUSSION}

\section{Lake Constance DIC Fluxes}

Figure 2 provides an overview of the DIC cycle of Lake Constance. Based on the lake volume, which varies between 47.2-48.2 $\mathrm{km}^{3}$ (Bäuerle et al. 1998) and lake water DIC concentrations (IGKB 1976; Hirschfeld 2003; this study), Lake Constance contains between 1380 and $1450 \mathrm{GgC}$ in the form of DIC. The rivers deliver $350-380 \mathrm{GgC} / \mathrm{yr}$ of DIC and the Rhine releases $300-350 \mathrm{GgC} / \mathrm{yr}$ based on long-term average river fluxes (Gilfedder et al. 2010) and riverine DIC concentrations (Hirschfeld 2003). Based on a range of possible rainwater DIC concentrations (Górka et al. 2011), precipitation (Gilfedder et al. 2010) introduces $0.3-3 \mathrm{GgC}$ of DIC annually. Within the lake, the sedimentation of lacustrine calcite and organic matter remove between $10-40 \mathrm{GgC} / \mathrm{yr}$ from the DIC pool (Stabel 1986; Straile 1998). DIC from groundwater and water contributions from overland flow are loosely constrained. Based on the flux (Gilfedder et al. 2010) and an assumed DIC concentration equal to that of riverine sources (Hirschfeld 2003), an estimated flux of $10 \mathrm{GgC} / \mathrm{yr}$ into Lake Constance is proposed. On average, Lake Constance receives an average of $3.70 \mathrm{Tg}$ of total sediment sourced from its terrestrial catchment annually (Gilfedder et al. 2010). Assuming an organic carbon content of $1 \%$ of soil and plant debris origin, this would amount to $40 \mathrm{GgC}$ of pedogenic origin entering Lake Constance annually. Terrestrial organic matter constitutes a source of lacustrine DIC if remineralized in the lake. This variable DIC source is discussed further in the following sections. Based on the maximum and minimum DIC input and output scenarios, the amount of carbon evading the lake along the air-water interface is constrained within the range of -20 to $+130 \mathrm{GgC} / \mathrm{yr}$ (with positive values representing the net release of carbon dioxide to the atmosphere). The corresponding water surface area normalized rates of carbon dioxide release range from $-0.1 \mathrm{gC} / \mathrm{m}^{2} /$ day to $0.7 \mathrm{gC} / \mathrm{m}^{2} /$ day (with positive values representing the net release of carbon dioxide to the atmosphere), which is within the typical range of carbon dioxide fluxes along airwater interfaces of lakes (Cole et al. 1994; Huotari et al. 2011). 
Table $1{ }^{14} \mathrm{C}$ isotopic composition of DIC from Lake Constance.

\begin{tabular}{|c|c|c|c|c|c|c|}
\hline Location & $\begin{array}{l}\text { Collection } \\
\text { date } \\
\text { (d.mo.yr) }\end{array}$ & $\begin{array}{l}\text { Water } \\
\text { depth (m) }\end{array}$ & $\begin{array}{l}\text { DIC } \\
\text { concentration } \\
(\mu \mathrm{gC} / \mathrm{mL})\end{array}$ & $\begin{array}{l}\mathrm{DI}^{14} \mathrm{C} \\
(\mathrm{Fm})\end{array}$ & $\begin{array}{l}\text { Fm } \\
\text { absolute } \\
\text { error }( \pm)\end{array}$ & Source \\
\hline$\overline{\mathrm{FG}}$ & 14.08 .2013 & 1 & 26 & 0.858 & 0.002 & This study \\
\hline FG & 14.08 .2013 & 5 & 26 & 0.853 & 0.002 & This study \\
\hline FG & 14.08 .2013 & 10 & 28 & 0.851 & 0.002 & This study \\
\hline FG & 14.08 .2013 & 15 & 28 & 0.855 & 0.002 & This study \\
\hline FG & 14.08 .2013 & 20 & 30 & 0.856 & 0.002 & This study \\
\hline FG & 14.08 .2013 & 50 & 32 & 0.864 & 0.002 & This study \\
\hline Sipplingen & 17.04.1969 & Surface & - & $\begin{array}{l}1.26 \\
(1.26-1.27)^{*}\end{array}$ & - & Kölle (1969) \\
\hline Sipplingen & 17.04.1969 & 40 & - & $\begin{array}{l}1.20 \\
(1.19-1.21)^{*}\end{array}$ & - & Kölle (1969) \\
\hline Lindau & 17.04.1969 & Surface & - & $\begin{array}{l}1.25 \\
(1.24-1.26)^{*}\end{array}$ & - & Kölle (1969) \\
\hline Lindau & 17.04.1969 & 40 & - & $\begin{array}{l}1.14 \\
(1.13-1.14)^{*}\end{array}$ & - & Kölle (1969) \\
\hline
\end{tabular}

${ }^{*}$ Units in parentheses are ranges of $\mathrm{DI}^{14} \mathrm{C}$ values generated assuming -5 and $-11 \%$ for the ${ }^{13} \mathrm{C}$-based fractionation correction of data reported by Kölle (1969).

\section{Assessing Atmospheric Carbon Contribution}

At location FG, water column-suspended DIC collected at six different depths averaged $0.856 \pm 0.005 \mathrm{Fm}$, with most measured values within error of one another and no clear trend in the water column (see Table 1). Data collected by Kölle (1969), converted to Fm values, show surface waters that are higher by 0.06 and $0.11 \mathrm{Fm}$ units for Sipplingen and Lindau, respectively.

In a simplified scheme, we can consider that DIC originates from petrogenic (i.e., limestonederived) and from atmospheric sources, which can be described with the binary mixing model in Equation 4:

$$
\mathrm{Fm}_{\mathrm{DIC}}=(1-x) * \mathrm{Fm}_{\text {petro }}+x * \mathrm{Fm}_{\text {atm }}
$$

where $x$ represents the relative contribution of atmospheric-derived carbon. In this case, carbon derived from the weathering of ancient limestone is characterized by a ${ }^{14} \mathrm{C}$-dead isotopic composition as the limestone formations in the Lake Constance catchment are millions of years old (Hsü 1995) and thus characterized by a ${ }^{14} \mathrm{C}$ isotopic composition of $\mathrm{Fm}_{\text {petro }}=0$. The proportion of atmospherically derived carbon in lacustrine DIC integrates over all contributions of DIC from gas exchange along the air-water interface, degradation of soil organic matter, rainwater inputs, groundwater and overland flow inputs, and riverine inputs, which in turn integrate over atmospheric and petrogenic contributions from chemical weathering of rocks and air-water gas exchange along the transport path. Given the low DIC residence time in Lake Constance (4-5 years), loss of ${ }^{14} \mathrm{C}$ by radioactive decay is considered negligible.

${ }^{14} \mathrm{C}$ isotopic composition for atmospheric carbon dioxide was 1.54 and $1.02 \mathrm{Fm}$ in the years 1969 and 2013, respectively (Levin and Kromer 2004; Graven 2015), primarily reflecting the temporal proximity to the bomb peak in atmospheric ${ }^{14} \mathrm{C}$. Based on isotope mass balance calculations of the minimum and maximum measured $\mathrm{DI}^{14} \mathrm{C}$ concentrations, the contribution 
of atmosphere-derived carbon to Lake Constance corresponds to $83-85 \%$ in 2013 . In 1969 , the atmospheric proportion contributing to lake water DIC lies between 73 and $82 \%$ when, in addition to considering the extreme $\mathrm{DI}^{14} \mathrm{C}$ endpoints of Lindau $(40 \mathrm{~m})$ and Sipplingen surface waters, the ${ }^{13} \mathrm{C}$-based fractionation-based sensitivity analysis is applied. Given these two constraints, it suggests a modest but significant increase in atmospheric carbon contributions to Lake Constance DIC over the four decades between the two sample collection times.

\section{Mechanisms for Changes in $\mathrm{DI}^{14} \mathrm{C}$ over Time}

There are various factors that may lead to changes in the ${ }^{14} \mathrm{C}$ isotopic composition of lake water DIC with time. The alkalinity of the water and the bedrock of the catchment exert first order control on the $\mathrm{DI}^{14} \mathrm{C}$ value (Keaveney and Reimer 2012). Depending on the stoichiometry of the bedrock weathering reaction, the carbon may entirely be sourced from the atmosphere (Equation 3), from equal proportions of atmospheric and ancient bedrock sources (Equation 1), or entirely from ancient carbonate (Equation 2). Changes in weathering behavior of bedrock could thus lead to changes in $\mathrm{DI}^{14} \mathrm{C}$. Another source of change may come from the intensity of gas exchange between air and water. Greater exchange would lead to $\mathrm{DI}^{14} \mathrm{C}$ approaching an atmospheric ${ }^{14} \mathrm{C}$ content. This may in turn also be related to lake water circulation controlling water mass exposure to the air-water interface. The replacement and vertical mixing of deep waters is expected to change with future changes in climate and precipitation (Fink et al. 2016). Similar to vertical mixing, the export of organic remains from photosynthetic organisms into deep waters and their subsequent degradation offers another pathway by which surface water DIC can contribute to deep water DIC (Schwalb et al. 2013). A further source of carbon that may influence $\mathrm{DI}^{14} \mathrm{C}$ within the lake is that resulting from the degradation of allochthonous organic matter introduced to the lake by riverine or atmospheric transport. Allochthonous organic matter and products formed from its degradation are utilized by aquatic microorganisms and thus this carbon can propagate through the lacustrine food web before finding its way into the lacustrine DIC reservoir (Fuentes et al. 2013b). Oxidation of allochthonous organic matter and intermediate degradation products such as methane (Bussmann et al. 2013) will contribute more directly to lake water DIC. Soil organic matter, constituting an important component of allochthonous organic carbon supplied to Lake Constance by rivers (Fuentes et al. 2013a), is characterized by relatively modern ${ }^{14} \mathrm{C}$ isotopic compositions (van der Voort et al. 2016). Increased degradation of soil organic matter within Lake Constance sediments may thus to lead to an increase in atmospheric carbon contribution to water column DIC, and vice versa.

The most striking difference between Lake Constance in 2013 and 1969 is its nutrient state, as echoed by changes in lake ecology (Wessels et al. 1999). Due to anthropogenic activity, Lake Constance successively increased its nutrient state transitioning from oligotrophic to mesotrophic in 1939, and with advanced eutrophication beginning in the mid 1950s. Eutrophication continued until 1979/1980 when phosphorous concentrations reached their peak (Wessels et al. 1999). During this time of intensified lacustrine primary productivity, lacustrine and terrestrial organic matter sourced from the catchment was subject to enhanced preservation in the lake sediments, particularly along the margins, due to reduced water column oxygen conditions which even reached an anoxic, sulfidic state (Müller 1966). In the newfound oligotrophic state of the lake with oxic bottom waters, terrestrial organic carbon provides an important substrate for microbes, which provides a source of carbon for benthic organisms (Sobek et al. 2009; Fuentes et al. 2013b), allowing soil carbon to act as a vector for transferring atmospheric carbon into lake water DIC. Based on the historically documented changes in the carbon cycle of Lake Constance, we hypothesize that the inhibition of soil organic matter degradation led to a decreased transformation of ${ }^{14} \mathrm{C}$-enriched soil carbon into DIC, which in turn indirectly results in a net reduction in the atmospheric carbon contribution to the DIC pool. The amount of soil organic carbon entering 
Lake Constance corresponds to about 3\% of the size of the total Lake Constance DIC pool (see Figure 2). With a 4- to 5-year residence time for DIC in the lake, integrated over the course of a few years, diminished soil organic carbon degradation and the corresponding decreased contribution to the aquatic DIC pool can account for the lower atmospheric carbon contributions to the DIC pool in the late 1960s. Thus, changes in the remineralization behavior of allochthonous soil organic carbon due to eutrophication may influence lacustrine $\mathrm{DI}^{14} \mathrm{C}$ inventories.

Other superimposed effects can introduce additional influence on $\mathrm{DI}^{14} \mathrm{C}$. The utilization of DIC by photosynthetic organisms can lead to higher uptake of atmospheric $\mathrm{CO}_{2}$ leading to higher $\mathrm{DI}^{14} \mathrm{C}$ signatures (Kempe 1982; Li et al. 2017). In the case of Lake Constance, ${ }^{14} \mathrm{C}$ data reveals that atmospheric carbon contributions in the eutrophic waters of 1969 were lower than today. This is contrary to what would be expected in a freshwater system with elevated primary productivity, and suggests that - despite eutrophication - direct assimilation of atmospheric $\mathrm{CO}_{2}$ into lake water DIC was significantly outweighed by the effects of reduced remineralization of soil organic carbon. Other mechanisms for changing $\mathrm{DI}^{14} \mathrm{C}$ cannot be wholly excluded based on the available data. Given however the pervasive changes introduced by eutrophication in various aspects of the Lake Constance carbon cycle and ecosystem (Müller 1966, 1997; Güde et al. 1998; Wessels et al. 1999), and little reason to assume large changes in the other mechanisms, this hypothesis provides a realistic explanation aligned with historically documented changes.

\section{Projections for Past and Future $\mathrm{DI}^{14} \mathrm{C}$}

Based on the above line of reasoning, we propose an estimate of $\mathrm{DI}^{14} \mathrm{C}$ for a pre-eutrophication, pre-industrial, and pre-bomb Lake Constance. In pre-industrial Lake Constance, prior to the earliest signs of eutrophication in 1870-1880 (Müller 1997), the oligotrophic state of today likely best characterizes the $\mathrm{DI}^{14} \mathrm{C}$ lake as it once may have been. We thus project the pre-anthropogenic Lake Constance DIC atmospheric contribution to be around $83-85 \%$, corresponding to an Fm value of $0.83-0.85$ for lake water $\mathrm{DI}^{14} \mathrm{C}$. Besides eutrophication, another difference between Lake Constance today and in the 19th century was the change in circulation induced by the channelization of the Rhine (Wasmund 1928), which may have had additional effects on lake-atmosphere $\mathrm{CO}_{2}$ exchange. Furthermore, changes in land use, deforestation, fertilizer usage, and erosion (Güde et al. 1998) introduce additional uncertainty and may lead to error in our projection.

Based on the estimates of $83-85 \%$ atmospheric carbon contributing to Lake Constance DIC, we expect that in the year 2100, following the predictions by Graven (2015) with a "business-as-usual" fossil fuel emission scenario ( $\mathrm{RCP} 8.5, \mathrm{Fm}_{\text {atmosphere }}=0.73$ ), a DI ${ }^{14} \mathrm{C}$ signature of $0.61-0.62 \mathrm{Fm}$ is predicted. However, concurrent to depletion in atmospheric ${ }^{14} \mathrm{C}$, lake water temperatures are experiencing an observable increase, and this increase is projected to continue (IGKB 2015, O'Reilly et al. 2015). The resulting increase in water column stratification will decrease exchange between atmospheric and deep water DIC pools, but, more significantly, also lead to depletion in bottom water oxygen concentrations. This may create a situation similar to the 1960s, which saw as little as $74 \%$ atmospheric contributions. If this scenario were to be realized then, $\mathrm{DI}^{14} \mathrm{C}$ may reach $0.54 \mathrm{Fm}$ by the end of the century. The projection range for Lake Constance $\mathrm{DI}^{14} \mathrm{C}$, $0.54-0.62 \mathrm{Fm}$, for the year 2100 corresponds to a reservoir age of $3800-5000 \mathrm{Libby}{ }^{14} \mathrm{C}$ years before present. Globally, $\mathrm{DI}^{14} \mathrm{C}$ from other hardwater lakes and rivers will likely follow a similar trend. Based on these projections, assuming linear changes, and taking the $85 \%$ and $74 \%$ atmospheric contribution scenarios, the difference to 2013 measured values would exceed $0.02 \mathrm{Fm}$ units within 8 and 6 years, respectively, rendering it possible to track such changes well beyond margins of analytical uncertainty within the course of a single decade. Larger lakes with relatively little DIC sourced from carbonate weathering and influence from terrestrial organic carbon, e.g., 
Lake Superior (Zigah et al. 2012), will likely show a $\mathrm{DI}^{14} \mathrm{C}$ trajectory more tightly coupled to atmospheric ${ }^{14} \mathrm{C}$ content both in terms of absolute ${ }^{14} \mathrm{C} /{ }^{12} \mathrm{C}$ ratio and rate of change. Similarly, lakes situated in endorheic basins may exhibit $\mathrm{DI}^{14} \mathrm{C}$ values mirroring atmospheric values due to extensive air-water gas exchange, as found for several Chinese lakes (T. Liu et al. 2017). Lakes exhibiting limited mixing characteristics might show lagged and muted responses, e.g., meromictic lakes such as Lac Pavin, France (Albéric et al. 2013). Additionally, lake geometry (surface area to volume ratio), and changes thereof, control gas exchange with the atmosphere and can lead to additional changes in the reservoir effect over time periods of millennia to centuries (e.g., Schleinsee, Germany; Geyh et al. 1998).

Deviations from these $\mathrm{DI}^{14} \mathrm{C}$ projections from Lake Constance exposed by future measurements, will shed light on processes we have not considered or underestimated here, or further carbon cycle perturbations. Deviations from these forecasts may reflect additional changes in lake hydrology, chemical weathering of rocks in the catchment or other changes in DIC source. In coming decades, Lake Constance and lakes globally are likely to undergo significant hydrological change due to modification of precipitation patterns, runoff, vertical mixing, and other processes linked to climate change (Battin et al. 2009; Tranvik et al. 2009; Fink et al. 2016). With ongoing rising water temperatures observed for Lake Constance (IGKB 2015) and for lakes globally (O'Reilly et al. 2015), it is becoming increasingly important to understand how these changes will affect lakes as carbon sinks, ecosystems, and as a water resource for humans.

\section{SUMMARY AND OUTLOOK}

Future work on Lake Constance and other water bodies will need to consider the impact of changing $\mathrm{DI}^{14} \mathrm{C}$ to assign end-member ${ }^{14} \mathrm{C}$ values to aquatic primary productivity for the purpose of both natural isotope tracing and ${ }^{14} \mathrm{C}$ dating studies. Bomb-derived carbon as well as the continued release of fossil fuel-derived $\mathrm{CO}_{2}$ are set to continue the isotopic perturbation of carbon reservoirs including the hydrosphere (Graven 2015). Changes in DIC sources include supply of terrestrial organic carbon to lakes and its degradation behavior, with the latter coupled to lake water oxygen content. Additional changes to DIC source may stem from changes in carbonate and silicate rock weathering as well as changes in air-water gas exchange. Coeval changes in climate and anthropogenic impacts will lead to a variety of superimposed effects modulating $\mathrm{DI}^{14} \mathrm{C}$ in terrestrial water bodies. Time-series monitoring of ${ }^{14} \mathrm{C}$ in lake water DIC and other carbon reservoirs provide important constraints on the origin and trajectories of change in carbon cycle processes.

\section{ACKNOWLEDGMENTS}

Daniel Montluçon is thanked for his technical support in the laboratory. We thank Lukas Wacker, Martin Suter, and Mantana Maurer for their support in the Laboratory of Ion Beam Physics at ETH Zurich. For collecting samples in Lake Constance, we thank the crew of R/V Kormoran and Klaus Weih (ISF Langenargen) for acquisition and processing of water column data.

\section{REFERENCES}

Albéric P, Jézéquel D, Bergonzini L, Chapron E, Viollier E, Massault M, Michard G. 2013. Carbon cycling and organic radiocarbon reservoir effect in a meromictic crater lake (Lac Pavin, Puy-deDôme, France). Radiocarbon 55(2-3):1029-42. doi: 10.1017/S0033822200058161.

Battin TJ, Luyssaert S, Kaplan LA, Aufdenkampe AK, Richter A, Tranvik LJ. 2009. The boundless carbon cycle. Nature Geoscience 2:598-600. doi: 10.1038/ngeo618.

Bäuerle E, Ollinger D, Ilmerger J. 1998. Some meteorological, hydrological, and hydrodynamical aspects of Upper Lake Constance. Advances in Limnology 53:31-83.

Blattmann TM, McIntyre CP, Wacker L, Eglinton TI. 2013. Graphitization of dissolved inorganic carbon: 
procedures for AGE preparation of water samples for $\mathrm{DI}^{14} \mathrm{C}$ analysis. Laboratory of Ion Beam Physics Annual Report 28.

Broecker WS, Walton A. 1959a. Radiocarbon from nuclear tests. Science 130(3371):309-14.

Broecker WS, Walton A. 1959b. The geochemistry of $\mathrm{C}^{14}$ in fresh-water systems. Geochimica et Cosmochimica Acta 16(1):15-38. doi: 10.1016/ 0016-7037(59)90044-4.

Bussmann I, Damm E, Schlüter M, Wessels M. 2013. Fate of methane bubbles released by pockmarks in Lake Constance. Biogeochemistry 112(1): 613-23. doi: 10.1007/s10533-012-9752-x.

Cole JJ, Caraco NF, Kling GW, Kratz TK. 1994. Carbon dioxide supersaturation in the surface waters of lakes. Science 265(5178):1568-70. doi: 10.1126/science.265.5178.1568.

Fink G, Wessels M, Wüest A. 2016. Flood frequency matters: Why climate change degrades deep-water quality of peri-alpine lakes. Journal of Hydrology 540:457-68. doi: 10.1016/j.jhydrol.2016.06.023.

Fuentes N, Güde H, Wessels M, Straile D. 2013a. Allochthonous contribution to seasonal and spatial variability of organic matter sedimentation in a deep oligotrophic lake (Lake Constance). Limnologica 43:122-30. doi: 10.1016/j.limno. 2012.06.003.

Fuentes N, Güde H, Straile D. 2013b. Importance of allochthonous matter for profundal macrozoobenthic communities in a deep oligotrophic lake. International Review of Hydrobiology 98(1):1-13. doi: 10.1002/iroh.201201532.

Geyh MA, Schotterer U, Grosjean M. 1998. Temporal changes of the ${ }^{14} \mathrm{C}$ reservoir effect in lakes. Radiocarbon. 40(2):921-31. doi: 10.1017/ S0033822200018890.

Gilfedder BS, Petri M, Wessels M, Biester H. 2010. An iodine mass-balance for Lake Constance, Germany: insights into iodine speciation changes and fluxes. Geochimica et Cosmochimica Acta 74 (11):3090-111. doi: 10.1016/j.gca.2010.03.008.

Górka M, Sauer PE, Lewicka-Szczebak D, Jędrysek M-O. 2011. Carbon isotope signature of dissolved inorganic carbon (DIC) in precipitation and atmospheric $\mathrm{CO}_{2}$. Environmental Pollution 159(1): 294-301. doi: 10.1016/j.envpol.2010.08.027.

Graven HD. 2015. Impact of fossil fuel emissions on atmospheric radiocarbon and various applications of radiocarbon over this century. Proceedings of the National Academy of Sciences of the United States of America 112(31):9542-5. doi: 10.1073/pnas.1504467112.

Güde H, Rossknecht H, Wagner G. 1998. Anthropogenic impacts on the trophic state of Lake Constance during the $20^{\text {th }}$ century. Advances in Limnology 53:85-108.

Guillemette F, Bianchi TS, Spencer RGM. 2017. Old before your time: Ancient carbon incorporation in contemporary aquatic foodwebs. Limnology and Oceanography 1-19. doi: 10.1002/lno.10525.
Hirschfeld M. 2003. Isotopen- und Hydrochemie des Rheinsystems: Saisonale Variationen als Konsequenz dynamischer Prozessabläufe des kontinentalen Kohlenstoff- und Wasserkreislaufes. Kölner Forum für Geologie und Paläontologie 12:1-71.

Hollander DJ, McKenzie JA. 1991. $\mathrm{CO}_{2}$ control on carbon-isotope fractionation during aqueous photosynthesis: A paleo- $\mathrm{pCO}_{2}$ barometer. Geology 19(9):929-32. doi: 10.1130/0091-7613(1991) $019<0929$ :ccocif $>2.3 . \operatorname{co} ; 2$.

Hsü KJ. 1995. The Geology of Switzerland: An Introduction to Tectonic Facies. Princeton, NJ: Princeton University Press. p 250.

Huotari J, Ojala A, Peltomaa E, Nordbo A, Launiainen S, Pumpanen J, Rasilo T, Hari P, Vesala T. 2011. Long-term direct $\mathrm{CO}_{2}$ flux measurements over a boreal lake: five years of eddy covariance data. Geophysical Research Letters 38(18). doi: 10.1029/2011GL048753.

Ishikawa NF, Tayasu I, Yamane M, Yokoyama Y, Sakai S, Ohkouchi N. 2015. Sources of dissolved inorganic carbon in two small streams with different bedrock geology: insights from carbon isotopes. Radiocarbon 57(3):439-48. doi: 10.2458/ azu_rc.57.18348.

IGKB 1976. Jahresbericht über den limnologischen Zustand des Bodensees. Grüner Bericht. Internationale Gewässerschutzkommission für den Bodensee. p 1-44.

IGKB 2009. Bodensee-Untersuchung-Seeboden. Das BUS-Forschungsprojekt 2003-2006. Blauer Bericht: Internationale Gewässerschutzkommission für den Bodensee. $58 \mathrm{p}$.

IGKB 2015. KlimBo - Klimawandel am Bodensee. Blauer Bericht: Internationale Gewässerschutzkommission für den Bodensee. $60 \mathrm{p}$.

IGKB 2016. Tiefenschärfe - Hochauflösende Vermessung des Bodensees. Blauer Bericht. Internationale Gewässerschutzkommission für den Bodensee. 61 p. 109.

Keaveney EM, Reimer PJ. 2012. Understanding the variability in freshwater radiocarbon reservoir offsets: a cautionary tale. Journal of Archaeological Science 39(5):1306-16. doi: 10.1016/j. jas.2011.12.025.

Kempe S. 1982. Long-term records in $\mathrm{CO}_{2}$ pressure fluctuations in fresh waters. Mitteilungen aus dem Geologischen-Paläontologischen Institut der Universität Hamburg 52:91-332.

Kölle W. 1969. Untersuchungen zur organischen Belastung des Rheins und deren Herkunft. Vom Wasser 36:34-53.

Levin I, Kromer B. 2004. The tropospheric ${ }^{14} \mathrm{CO}_{2}$ level in mid-latitudes of the Northern Hemisphere (1959-2003). Radiocarbon 46(3):1261-71. doi: 10.2458/rc.v46i3.4181.

Li Y, Qiang M, Jin Y, Liu L, Zhou A, Zhang J. 2017. Influence of aquatic plant photosynthesis on the reservoir effect of Genggahai Lake, northeastern Qinghai-Tibetan Plateau. Radiocarbon. doi: 10.1017/RDC.2017.127. 
Liu T, Zhou W, Cheng P, Burr GS. 2017. A survey of the ${ }^{14} \mathrm{C}$ content of dissolved inorganic carbon in Chinese lakes. Radiocarbon, doi: 10.1017/RDC.2017.113.

Liu Z, Zhao M, Sun H, Yang R, Chen B, Yang M, Zeng Q, Zeng H. 2017. "Old” carbon entering the South China Sea from the carbonate-rich Pearl River Basin: coupled action of carbonate weathering and aquatic photosynthesis. Applied Geochemistry 78:96-104. doi: 10.1016/ j.apgeochem.2016.12.014.

Müller G. 1966. Die Verteilung von Eisenmonosulfid (FeS.nH2O) und organischer Substanz in den Bodensedimenten des Bodensees - ein Beitrag zur Frage der Eutrophierung des Bodensees. Gas und Wasserfach 107(14):364-8.

Müller G. 1997. Chronologie des anthropogenen Phosphor-Eintrags in den Bodensee und seine Auswirkung auf das Sedimentationsgeschehen. In: Matschullat J, Tobschall HJ, Voigt H-J, editors. Geochemie und Umwelt: Relevante Prozesse in Atmo-, Pedo- und Hydrosphäre. Berlin, Heidelberg: Springer. p 317-42. doi: 10.1007/9783-642-59038-2_19.

O'Reilly CM, Sharma S, Gray DK, Hampton SE, Read JS, Rowley RJ, Schneider P, Lenters JD, McIntyre PB, Kraemer BM, Weyhenmeyer GA, Straile D, Dong B, Adrian R, Allan MG, Anneville O, Arvola L, Austin J, Bailey JL, Baron JS, Brookes JD, de Eyto E, Dokulil MT, Hamilton DP, Havens K, Hetherington AL, Higgins SN, Hook S, Izmest'eva LR, Joehnk KD, Kangur K, Kasprzak P, Kumagai M, Kuusisto E, Leshkevich G, Livingstone DM, MacIntyre S, May L, Melack JM, Mueller-Navarra DC, Naumenko M, Noges P, Noges T, North RP, Plisnier P-D, Rigosi A, Rimmer A, Rogora M, Rudstam LG, Rusak JA, Salmaso N, Samal NR, Schindler DE, Schladow SG, Schmid M, Schmidt SR, Silow E, Soylu ME, Teubner K, Verburg P, Voutilainen A, Watkinson A, Williamson CE, Zhang G. 2015. Rapid and highly variable warming of lake surface waters around the globe. Geophysical Research Letters 42(24):10,773-81. doi: 10.1002/ 2015 GL066235.

Schwalb A, Dean W, Güde H, Hanisch S, Sobek S, Wessels M. 2013. Benthic ostracode $\delta^{13} \mathrm{C}$ as sensor for early Holocene establishment of modern circulation patterns in Central Europe. Quaternary Science Reviews 66:112-22. doi: 10.1016/j. quascirev.2012.10.032.

Sobek S, Durisch-Kaiser E, Zurbrügg R, Wongfun N, Wessels M, Pasche N, Wehrli B. 2009. Organic carbon burial efficiency in lake sediments controlled by oxygen exposure time and sediment source. Limnology and Oceanography 54(6): 2243-54. doi: 10.4319/lo.2009.54.6.2243.

Stabel HH. 1986. Calcite precipitation in Lake Constance: Chemical equilibrium, sedimentation, and nucleation by algae. Limnology and Oceanography 31(5):1081-94. doi: 10.4319/lo.1986.31.5.1081.

Straile D. 1998. Biomass allocation and carbon flow in the pelagic food web of Lake Constance. In: Bäuerle E, Gaedke U. Lake Constance: characterization of an ecosystem in transition. Stuttgart 53:545-63.

Stenström KE, Skog G, Georgiadou E, Genberg J, Johansson A. 2011. A Guide to Radiocarbon Units and Calculations. p 17.

Suess HE. 1955. Radiocarbon concentration in modern wood. Science 122:415-7. doi: 10.1126/ science.122.3166.415-a.

Synal H-A, Stocker M, Suter M. 2007. MICADAS: A new compact radiocarbon AMS system. Nuclear Instruments and Methods in Physics Research B 259(1):7-13. doi: 10.1016/j.nimb.2007.01.138.

van der Voort TS, Hagedorn F, McIntyre C, Zell C, Walthert L, Schleppi P, Feng X, Eglinton TI. 2016. Variability in ${ }^{14} \mathrm{C}$ contents of soil organic matter at the plot and regional scale across climatic and geologic gradients. Biogeosciences 13(11):3427-39. doi: 10.5194/bg-13-3427-2016.

Wacker L, Němec M, Bourquin J. 2010. A revolutionary graphitisation system: fully automated, compact and simple. Nuclear Instruments and Methods in Physics Research B 268:931-4. doi: 10.1016/j.nimb.2009.10.067.

Wasmund E. 1928. Die Strömungen im Bodensee. Internationle Revue der gesamten Hydrobiologie und Hydrographie 19(1-2):21-155. doi: 10.1002/ iroh.19280190104.

Wessels M. 1998. Geological history of the Lake Constance area. In: Bäuerle E, Gaedke U, editors. Lake Constance: characterization of an ecosystem in transition. Stuttgart 53:1-12.

Wessels M, Mohaupt K, Kümmerlin R, Lenhard A. 1999. Reconstructing past eutrophication trends from diatoms and biogenic silica in the sediment and the pelagic zone of Lake Constance, Germany. Journal of Paleolimnology 21:171-92. doi: 10.1023/a:1008080922586.

Yu S-Y, Shen J, Colman SM. 2007. Modeling the radiocarbon reservoir effect in lacustrine systems. Radiocarbon 49(3):1241-54. doi: 10.1017/ S0033822200043150.

Zigah PK, Minor EC, Werne JP. 2012. Radiocarbon and stable-isotope geochemistry of organic and inorganic carbon in Lake Superior. Global Biogeochemical Cycles 26(1). doi: 10.1029/ 2011 GB004132. 